\title{
Ecology and biogeography of arbuscular mycorrhizal fungi belonging to the family Gigasporaceae in La Gran Sabana region (Guayana Shield), Venezuela.
}

\author{
${ }^{1}$ Lovera, M., ${ }^{1}$ Cuenca, G., ${ }^{2}$ Lau, P., ${ }^{3,4}$ Mavárez, J.
}

\begin{abstract}
Arbuscular mycorrhizal fungi (AMF) play a crucial role in ecosystem functioning improving plant nutrition and resistance to environmental stress. In La Gran Sabana (LGS), an upland belonging to the Venezuelan Guayana Shield, AMF are determinant for plant survival due to the acidic, sandy and oligotrophic nature of its soils. The vegetation is mainly constituted by savannas intermixed with forests, shrublands, meadows and palm swamps. In this region a high diversity of species of Gigasporacea has been found and four new species ( $S$. spinosissima, $S$. crenulata, $S$. striata, $S$. tepuiensis), as well as others undescribed morphotypes, are considered endemics. Some ecological and historical factors that could be involved with the restricted distribution of these species were evaluated. The high endemism of plants and the particular edaphic conditions present in shrublands looks like the main drivers of the important diversification processes within Gigasporacea detected in this region. The monophyletic origin of some of these endemic Gigasporaceae suggest that their endemism could be the result of a process of in situ diversification combined with limitations for dispersal and/or establishment in other regions. These findings and the presence of a basal lineage for the family allows proposing LGS as an evolutionary hotspot for Gigasporaceae.
\end{abstract}

Keywords: AMF- dispersion -endemic species -Glomeromycota-Scutellospora- diversification

M. Lovera (凹): mlovera2@gmail.com

${ }^{1}$ Instituto Venezolano de Investigaciones Científicas (IVIC), Apartado 20632, Caracas 1020-A, Venezuela.

${ }^{2}$ Universidad Experimental Simón Rodríguez (UNESR), Caracas 1204, Venezuela.

${ }^{3}$ Laboratoire d'Ecologie Alpine, UMR 5553 CNRS-Université Grenoble Alpes, BP 53, 2233 Rue de la Piscine, 38041 Grenoble, France.

${ }^{4}$ Departamento de Ciencias Biológicas y Ambientales, Universidad Jorge Tadeo Lozano, Cra 4 \#22-61, Bogotá, Colombia. 


\section{Introduction}

La Gran Sabana (LGS) is a large plateau in southeast Venezuela. It is part of the Canaima National Park, a protected area characterized by a high diversity and endemism of both plants and animals (Huber, 1994; Berry et al. 1995). LGS is located within $4^{\circ} 30^{\prime}-6^{\circ}$ $45^{\prime} \mathrm{N}$ and $60^{\circ} 34^{\prime}-62^{\circ} 50^{\prime} \mathrm{W}$ with altitudes from 1440 m.a.s.1. in the North to 800 m.a.s.1. in the South (Figure 1). With a complex mosaic of ecosystems, it is dominated by open savannas intermixed with other vegetation formations like forests, shrublands, meadows and palm swamps. The presence of sandstone mountains with a flat summit and vertical walls that can reach up to 3000 m.a.s.l. (tepuis), are a distinctive feature of the area. The parental substrate of the Guayana Shield, to which LGS belongs, are Precambrian quartzite and sandstone, one of the oldest materials on Earth (Briceño and Schubert 1990). High precipitation levels $(2500 \mathrm{~mm} /$ year $)$ and a very ancient parental substrate results in very acidic soils, highly weathered and low in nutrients (Fölster and Dezzeo 1994). In this harsh environment, the associations with soil microorganisms are crucial for the survival of plants.

Arbuscular mycorrhizas (AM) are ancient relations between soil fungi belonging to Glomeromycota phylum and the majority of land plants (Schüßler et al. 2001). In this association, the fungi depend on carbon supplied by host plants while the plants receive many benefits which include among others, a better $\mathrm{P}, \mathrm{N}, \mathrm{Zn}$ and $\mathrm{Cu}$ nutrition, increased tolerance to water stress, protection against root pathogens and enhanced soil structure. In LGS oligotrophic soils, many indigenous plants are expected to depend on mycorrhizas for survival. Indeed, most of the plants evaluated so far in this region, present high levels of mycorrhizal colonization (Cuenca and Lovera, 1992; Lovera and Cuenca, 1996; Rosales et al. 1997). Savannas have been present on LGS for at least 10 thousand years (Rull et al. 2016). Its area has increased at forests expense due to recurrent burning and other anthropic disturbances, including soil removal and mining that cause serious problems as soil erosion, water contamination and damage to plant communities.

Since the 1990s, our research group has conducted several studies in LGS aimed at assessing the diversity of arbuscular mycorrhizal fungi (AMF) present in both natural and disturbed areas. Findings indicated an important loss of AMF diversity produced by anthropic disturbances (Cuenca and Lovera 1992; Lovera and Cuenca 1996; Cuenca et al. 1998; Lovera and Cuenca 2007). The inventories carried out in the region indicate the existence of a high diversity of AMF and have allowed the detection of a large number of new species, many of which belong to the Gigasporaceae family. This family has been associated to sandy soils and it is particularly efficient transferring P to the plant (Lekberg et al. 2007, Veresoglou et al. 2012, Cahgnon et al. 2013), being very frequent in the oligotrophic soils characteristics of LGS. So far, 4 new species belonging to the family Gigasporaceae have been described in LGS: Scutellospora spinosissima (Walker et al. 1998), S. crenulata (Herrera-Peraza et al. 2001), S. striata (Cuenca and Herrera 2008) and S. tepuiensis (De Andrade et al. 2017). Additionally, other AMF morphotypes present in 
the region have unique characteristics, which are consistent with the idea that a significant proportion of the Glomeromycota diversity is expected to be found in the tropics (Cuenca and Lovera 2010, Chaudhary et al. 2017). Most of the new species of Gigasporaceae described for LGS have not been detected until now outside this region. Some of them are restricted to specific environments on a local scale and others are found coexisting in different ecosystems present throughout the study area. In the case of S. spinosissima, the restriction in its range of distribution is considered to be regional since this species has also been found in the Colombian Amazonian area (Peña-Venegas et al. 2006) and the Northeast of Brazil (Rabelo-Pereira et al. 2018). It is generally considered that microorganisms do not have dispersion restrictions, and therefore their taxa tend to be globally distributed (Finlay 2002). However, studies on the distribution of AMF on a global scale have found the existence of some patterns in their distribution among continents, climatic zones and ecosystems (Stürmer et al. 2018a, Öpik et al. 2010, Kivlin et al. 2011). Other studies such as Davison et al. (2015), find that AMFs have a predominantly cosmopolitan distribution, with a low proportion of endemism.

In this framework, the aim of this work is to evaluate the presence of the Gigasporaceae family in LGS in order to identify biotic and abiotic factors that could be involved in the presence of many endemisms of this group of AMF in this region of Venezuelan Guayana Shield. Additionally, information on the phylogenetic relationships of some species described in LGS region (S. spinosissima, S. crenulata and S. striata) and two putative new species ( $S$. sp1 and $S$. sp2) is included in order to explore the influence of its evolutionary history on the restricted nature of their distribution.

\section{Methods}

\subsection{Study area and characteristics of the biomes evaluated}

In order to assess the existence of particular ecological associations that could influence the distribution of species of the family Gigasporaceae in LGS, we registered their presence or absence in a number of localities covering the main types of natural ecosystems present in the region (savannas, shrublands, forests, herbaceous meadows and palm swamps). Most sampling sites were located in the northern sector of the plateau (Figure 1), between 1400-1000 m.a.s.l. Ecosystems are sub-mesothermal mountainous with mean annual temperature between $18-24{ }^{\circ} \mathrm{C}$. The most outstanding features of the natural ecosystems evaluated are the following:

Savannas. These are a mixture of grasses and sedges without woody elements, with a continuous herbaceous cover. Principal plant species are Trachypogon spicatus, Axonopus anceps, Paspalum carinatum, Leptocoryphium lanatum (Poaceae) and Rhynchospora barbata, Hypolytrum pulchrum, Scleria cyperina, Bulbostylis paradoxa, Lagenocarpus rigidus (Cyperaceae), among others. Soils are oxisols or entisols, very low in nutrients and strongly leached (Berry 1995, Huber 2006). 
Herbaceous meadows. These are herbaceous-type savannas where the dominant species are not grasses but broadleaf herbs. They are restricted in their extension and are always associated with humic soils (peat) saturated with water during a large part of the year. This type of ecosystem is dominated by species of Rapateaceae family as Stegolepis ptaritepuiensis and S. guianensis, rossete plants of Xyridaceae and Bromeliaceae families and subshrubs belonging to Rubiaceae and Ochnaceae. Its flora is related to the highlandtepuian flora and has a high proportion of endemisms (Schubert and Huber 1989).

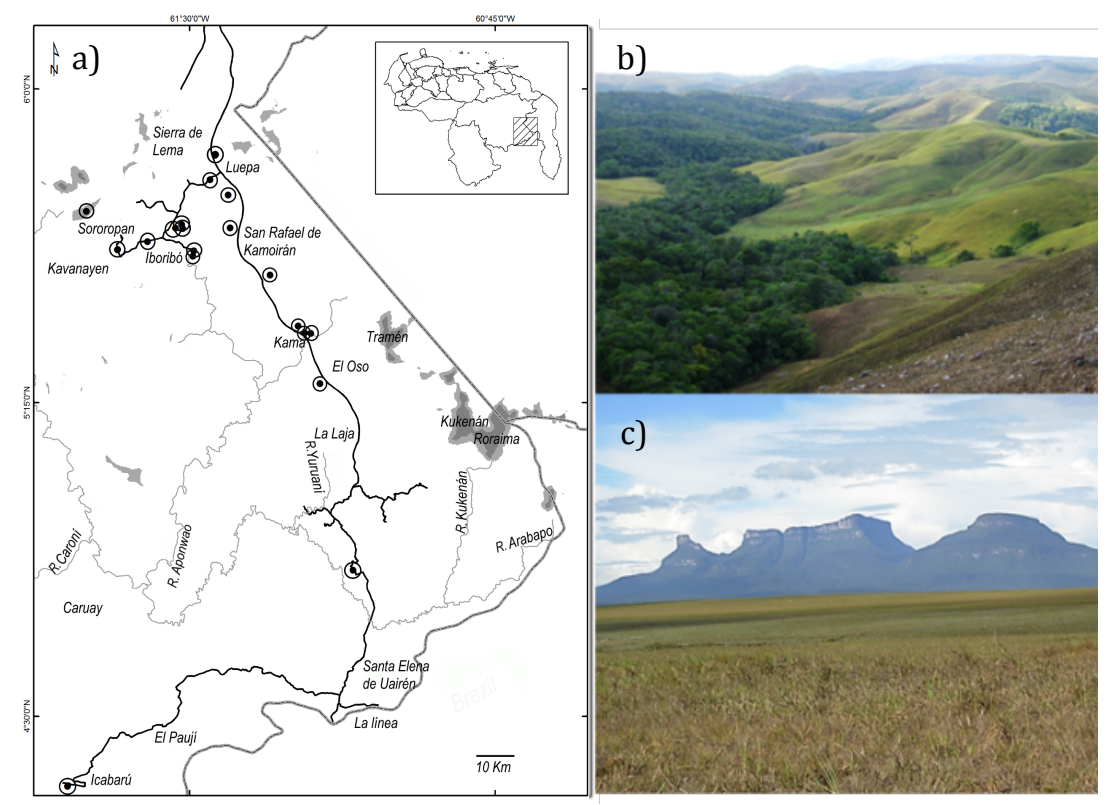

Figure 1. a) Location of La Gran Sabana (LGS). Circles indicate sampling site locations b) View of LGS landscape and c) Eastern tepui chain with Ilú-tepui at South and Tramen-tepui at North.

Sclerophyllous shrubs. This type of ecosystem grows on rocky sandstone substrates, or on deep sand areas of alluvial origin (Huber 1994). It presents a woody component of low height $(2-3 \mathrm{~m})$. Its flora is largely autochthonous, with many endemic plant species. It consists mainly of slow growth sclerophyllous leaf shrubs adapted to edaphic environments with severe water and nutritional deficiencies. Plant species that occur frequently are: Bonnetia sessilis (Bonnetiaceae), Clusia pusilla (Clusiaceae), Gongylolepis benthamiana (Asteraceae), Euphronia guianensis (Vochysiaceae) (Huber 1995).

Forests. Growing generally associated to diabase outcrops, adjacent to lowland bottoms of tepuis and areas bordering water bodies. They are mostly in the form of islands of variable size, medium height $(15-25 \mathrm{~m})$ and form a closed canopy. The dominant families are usually Legumes, Lauraceae, Vochysiaceae, Rubiaceae, Anonaceae and Burseraceae. In the understorey, shrubs, palms and herbs (heliconia type) occur (Schubert and Huber 1989).

Palm swamps. This type of ecosystem is formed by large patches of the palm Mauritia flexuosa (Arecaceae) that grow on alluvial plains covered by seasonally flooded savannas. 
They develop at lower altitude (750-1000 m.s.n.m.). In the herbaceous stratum, occur frequently Hypogynum virgatum, Andropogon spp. and Panicum spp. (Poaceae), Rhynchospora and Bulbostylis spp. (Cyperaceae), and other herbs such as Waltheria spp. (Sterculiaceae). There are also low shrubs of the families Melastomataceae, Clusiaceae and Piperaceae (Schubert and Huber 1989).

\subsection{Collection of presence data of Gigasporaceae family in LGS}

The information about the presence of the family Gigasporaceae in LGS was obtained from the Glomeromycotan Herbarium of Venezuela (HGV), which harbors the reference specimens and the ecological information of the localities visited by our research group along two decades in this region. Many of the specimens of the HGV herbarium were re-evaluated in order to verify their identification according to the current status of the AMF taxonomy. The classification of Redecker et al. (2013) was followed together with other specialized literature:, original published descriptions of the species, INVAM at the West Virginia University, USA (http://invam.wvu.edu), Department of Plant Pathology, University of Agriculture in Szczecin, Poland (http://www.agro.ar.szczecin.pl/ jblaszkowski /) and Blaszkowski (2012).

The Gigasporaceae species present in LGS were divided into two groups according to its geographical distribution range for comparative purposes: 1) Endemic distribution (ED): species restricted to South America (include local and regional endemisms present in LGS), and 2) Wide distribution (WD): species which have been documented in South America and also in other continents or in the North American subcontinent (Table 1). Gigasporaceae species were classified as ED or WD on the basis of information available in the public databases MaarjAM (Öpik et al. 2010) and BD (Stürmer et al. 2018) and scientific literature including AMF inventories, however this classification should be considered as provisional, subject to changes as new geographic regions are evaluated.

\subsection{Statistical analysis}

The proportion of species with endemic distribution for different biomes was compared using a Pearson chi-square test for categorical data. Relationships between soil properties and species composition of Gigasporaceae were explored using a canonical correspondence analysis with Montecarlo permutation test (cca function, vegan package 2.5-2, R, Oksanen et al. 2018).

\section{Gigasporaceae family in different biomes of LGS}

Through the revision of the HGV herbarium, 18 species of Gigasporaceae are present in LGS, representing $34 \%$ of family diversity. The records of 5 scutellosporoid morphotypes that are considered putative new species were included in this analysis, adding a total of 23 
species for the region. Sclerophyllous shrublands harbored the greatest diversity of Gigasporaceae, with $82 \%$ of the total species present in LGS (Table 1). All endemic species of Gigasporaceae (ED group) was found in sclerophyllous shrublands being $S$. spinosissima, $S$. crenulata and $S$. sp1 the most frequent species in this biome (Table 1). This result is coincident with the proposal of $S$. spinosissima and $S$. crenulata as indicator species for shrublands of LGS (Chaudhary et al. 2017).

Table 1. Relative frequency of Gigasporaceae species with endemic or wide distribution present in different LGS ecosystems and mean soil properties of the sites where Gigasporaceae were collected.

\begin{tabular}{|c|c|c|c|c|c|c|c|}
\hline & & \multirow{3}{*}{ HMA } & & & & & \multirow[b]{2}{*}{$\begin{array}{c}\text { Palm } \\
\text { Swamp } \\
\text { (1) }\end{array}$} \\
\hline & & & $\begin{array}{c}\text { Savanna } \\
\text { (6) }\end{array}$ & $\begin{array}{c}\text { Meadow } \\
\text { (3) }\end{array}$ & $\begin{array}{c}\text { Shrubland } \\
\text { (9) }\end{array}$ & $\begin{array}{c}\text { Forest } \\
(5)\end{array}$ & \\
\hline & & & \multicolumn{5}{|c|}{ Relative Frequency } \\
\hline \multirow{9}{*}{$\begin{array}{l}\text { Endemic } \\
\text { distribution } \\
\text { (ED) }\end{array}$} & Scre & Scutellospora crenulata & & 0.33 & 0.66 & & 1.00 \\
\hline & Sspi & Scutellospora spinosissima & 0.33 & 0.66 & 1.00 & 0.40 & \\
\hline & Sstr & Scutellospora striata & 0.17 & & 0.22 & & \\
\hline & Step & Scutellospora tepuiensis & & & 0.11 & & \\
\hline & Ssp1 & Scutellospora sp1 & 0.33 & & 0.66 & 0.20 & 1.00 \\
\hline & Ssp2 & Scutellospora sp2 & 0.17 & 0.66 & 0.44 & 0.60 & \\
\hline & Ssp3 & Scutellospora sp3 & & & 0.22 & & \\
\hline & Ssp 4 & Scutellospora sp4 & & 0.33 & 0.22 & 0.20 & \\
\hline & Ssp5 & Scutellospora sp5 & & & 0.11 & & \\
\hline \multirow{15}{*}{$\begin{array}{c}\text { Wide } \\
\text { distribution } \\
\text { (WD) }\end{array}$} & Cgil & Cetraspora gilmorei & 0.17 & & & 0.20 & \\
\hline & Dbio & Dentiscutata biornata & $0.66^{1}$ & & 0.22 & & \\
\hline & Dcer & Dentiscutata cerradensis & & & 0.11 & & \\
\hline & Dret & Dentiscutata reticulata & 0.17 & & 0.33 & & \\
\hline & Dsav & Dentiscutata savannicola & 0.33 & & 0.33 & 0.20 & \\
\hline & Gdec & Gigaspora decipiens & 0.33 & & & 0.20 & \\
\hline & Ggig & Gigaspora gigantea & & & 0.44 & 0.40 & \\
\hline & Gmar & Gigaspora margarita & & & 0.11 & 0.20 & \\
\hline & Gram & Gigaspora ramisporophora & & & 0.11 & 0.40 & \\
\hline & Rtro & Racocetra tropicana & 0.17 & 0.33 & 0.22 & 0.40 & \\
\hline & Sare & Scutellospora arenicola & 0.17 & & 0.22 & & \\
\hline & Scal & Scutellospora calospora & 0.17 & & 0.66 & 0.40 & 1.00 \\
\hline & Sdip & Scutellospora dipapillosa & & & & & 1.00 \\
\hline & Sper & Scutellospora pernambucana & & & & 0.80 & \\
\hline & & Species richness & 12 & 5 & 19 & 13 & 4 \\
\hline
\end{tabular}

\begin{tabular}{lcccc} 
Soil properties & \multicolumn{4}{c}{ Mean values $^{2}$ (Standar deviation) } \\
\hline $\mathrm{pH}$ & $5.3(0.4)$ & $5.1(0.6)$ & $5.2(0.5)$ & $4.8(0.4)$ \\
$\mathrm{OM}(\%)$ & $3.9(1.6)$ & $17.1(5.1)$ & $10.4(7.2)$ & $6.3(3.1)$ \\
$\mathrm{N}(\%)$ & $0.2(0.1)$ & $0.5(1.0)$ & $0.2(0.6)$ & $0.2(1.5)$ \\
$\mathrm{P}(\mu \mathrm{g} / \mathrm{g})$ & $1.2(1.0)$ & $1.1(1.0)$ & $1.3(0.6)$ & $4.4(1.5)$ \\
Sand $(\%)$ & $65.2(11.7)$ & $80.0(0.0)$ & $88.6(7.0)$ & $83.3(5.1)$ \\
\hline
\end{tabular}

${ }^{1}$ Frequency values greater than 0.50 are indicated in bold, with the exception of the palm swamp ecosystem in which only one location was evaluated.

The predominance of ED group species in the herbaceous meadows, suggests ecological associations of the ED Gigasporaceae with this particular biome. However, 
scarce information available in the database for herbaceous meadows, and especially for palm swamps, represented a limitation for the analysis of these ecosystems. Some species such as $S$. tepuiensis, $S$. sp3, $S$. sp5 were restricted to a one type of biome (shrubland) and in the case of $S$. sp5 and $S$. tepuiensis were restricted to a single locality. In the case of $S$. tepuiensis this species has been found only at the top of the Sororopan tepui, it would be very interesting to carry out samplings in other tepuis of LGS to establish if its distribution is more widespread in highland tepuian ecosystems. Other Gigasporaceae species present in the tepui, S. spinosissima and R. tropicana, are also found in diverse ecosystems of LGS. In the case of $R$. tropicana, it is a species belonging to the WD group that is also found in Africa.

The remarkable richness of Gigasporaceae species and the endemisms reported mainly for Scutellospora in LGS are according to the findings of Stürmer et al. (2018) about the presence of this family in a frequency higher than expected in South America and the high proportion of species considered provisionally endemic for the genera Scutellospora (>50\%). In shrublands and forests of LGS, the Gigasporaceae family represents 26-32\% of the species richness within each location (Cuenca and Lovera, 2010, Chaudhary et al. 2017), while even greater dominance of Gigasporaceae (50-87\%) has been found in the savannas of Roraima (Brazil) (Stürmer et al. 2018b). Interestingly, both regions are part of the Guayana Shield, which suggests an association of Gigasporaceae to the particular ecological conditions of this geological basement.

\section{Ecological factors associated with the distribution of Gigasporaceae in LGS}

\subsection{Vegetation}

The presence of ED Gigasporaceae in the different biomes evaluated could be associated with their levels of plant endemism. Both shrublands and herbaceous meadows have a higher proportion of endemic plants than other biomes in LGS (Berry et al. 1995). Then, it was interesting to perform a Contingency Table Analysis (CTA) to evaluate if the proportion of ED Gigasporaceae species is greater in these biomes in comparison with the one found in the other types of vegetation of the region (savannas, forests and palm swamps). This comparison evidenced that ED species are present in shrublands and meadows in a significantly higher proportion than in other vegetation types pooled together (Pearson Chi-Square $=8.090, \mathrm{df}=1, \mathrm{P}=0.004$ ) (Figure 2). This result supports earlier findings obtained by Öpik et al. (2009) in which endemic putative AM fungi were associated with host plant species with narrower ecological and geographical ranges suggesting that preferential associations with endemic plants present in meadows and shrublands could have played a significant role in restricting the distribution of some of the ED Gigasporaceae species of LGS. This hypothesis could be tested in the future using molecular tools to characterize the AMF community associated with the group of endemic plants of these ecosystems. 


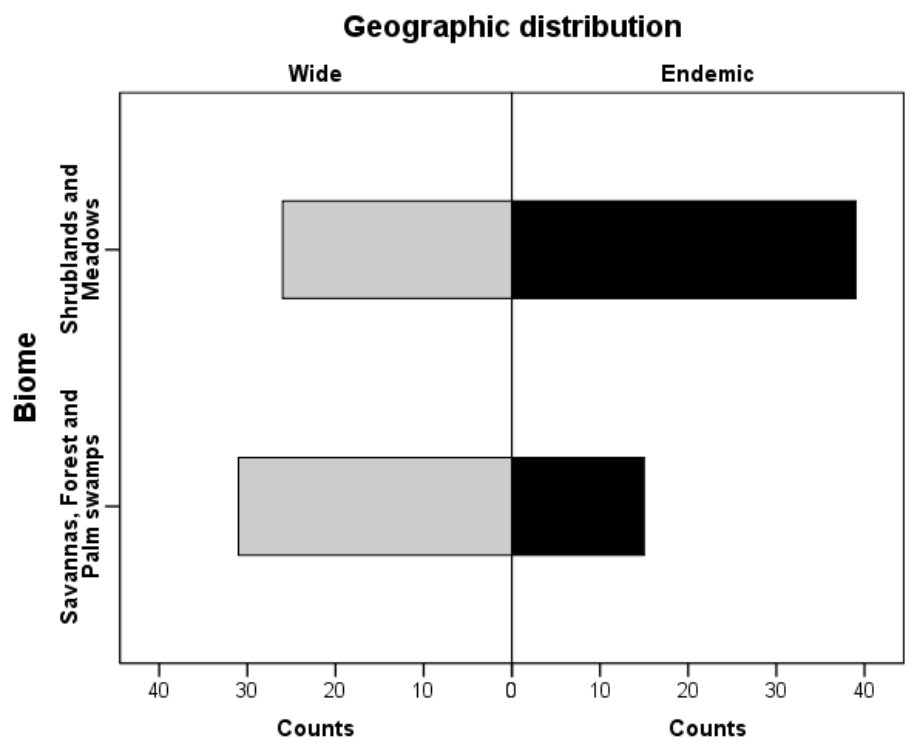

Figure 2. Presence records of the group of species of Gigasporaceae with wide and restricted range of distribution present in different ecosystems of LGS.

Differences in the structure of AMF communities found in ecosystems with different plant communities composition are commonly associated with variations in plantfungus function compatibility (Öpik et al. 2010, Kiers et al. 2011). However, the existence of specificity by the host in arbuscular mycorrhizal association is still a subject of debate. It has been proposed that the specificity of the mycorrhizal association in relation to the host plant can be better understood at a broader level, in ecological groups of plants, implying that plants with similar traits select symbionts that complement these traits (Öpik et al. 2009, Chagnon et al. 2015). Most of the ED Gigasporaceae species in this study, could be kept in trap pots only when they were found associated with native plants from herbaceous meadows (Stegolepis sp.) and shrubs (Clusia pusilla, Eucerea nitida, Gongylolepis benthamiana, Calliandra resupina, Pagameopsis garryoides, Macairea parviflora and Humiria balsamifera), plants that share adaptation strategies to edaphic environments with strong nutritional deficiencies.

\subsection{Soils}

The presence of AMF can be strongly linked with soil properties such as $\mathrm{pH}$ gradients, nutrient content and soil texture (Lekberg et al. 2011). In particular, oligothrophic soils and sandy texture are conditions favourable for the Gigasporaceae family (Landis et al. 2004, Lekberg et al. 2007, Cuenca and Lovera 2010). The species of this family develop a greater volume of extra-radical mycelium and, therefore, have a 
greater ability to capture water and nutrients, which makes them successful in environments where these resources are scarce (Hart and Reader 2002).

Soils in LGS are generally acidic, sandy and particularly low in available phosphorus, nevertheless sclerophyllous shrublands and herbaceous meadows grow on specific soil patches with singular characteristics: the former are found in deep sand areas and rock outcrops, while the latter grows on peat bogs with high levels of organic matter and nitrogen. These observations allow suggesting that the higher proportion of ED Gigasporaceae species in shrublands and meadows in LGS (Figure 2) could be related to the particular edaphic conditions of these ecosystems. To explore this idea, a Canonical Correspondence Analysis (CCA) was made on the set of records with edaphic information in the HGV database. It was found that the variables that explain most of the variation in the ordination of the species were the sand content, phosphorus and nitrogen levels (Figure 3). Organic matter was not included in the analysis because it had low significance and a high correlation with the percentage of nitrogen in previous analyses.

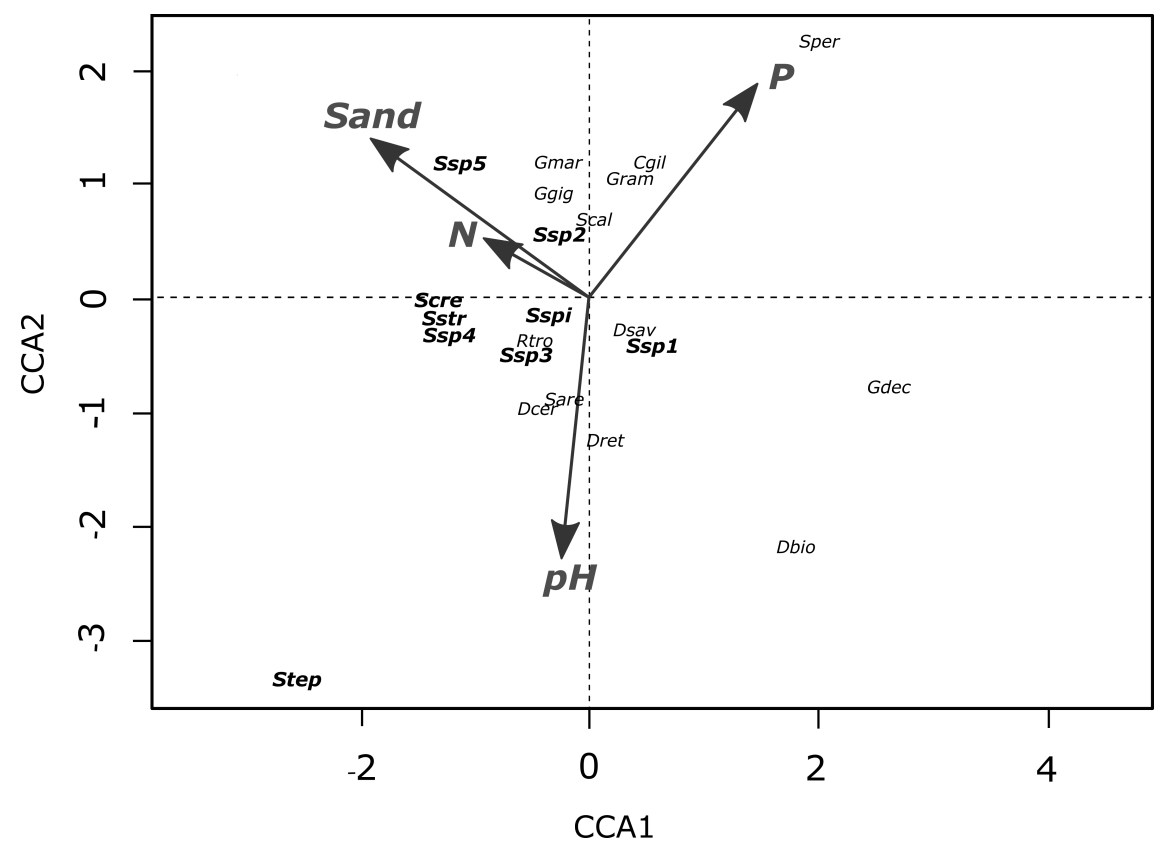

Figure 3. Canonical Correspondence Analysis (CCA) ordination plot of species of Gigasporaceae in La Gran Sabana (LGS). Species with restricted distribution (ED) are highlighted in bold. The constrained model is significant $(\mathrm{P}=0.002)$ and explains $33.4 \%$ of inertia. Explanatory variables: nitrogen $(\mathrm{F}=1.5939, \mathrm{P}=0.034, \mathrm{Df}=1)$, phosphorus $(\mathrm{F}=1.5807, \mathrm{P}=0.033, \mathrm{Df}=1)$ and sand $(\mathrm{F}=$ $1.9669, \mathrm{P}=0.004$, Df $=1$ ) are significant after a Permutation test by anova.cca function of vegan package in $\mathrm{R}$. The range of variation of edaphic parameters analysed were: $\mathrm{pH}$ (4.3-5.8), sand (6095\%), P (0.01-6.00 $\left.\mu \mathrm{g} . \mathrm{g}^{-1}\right)$, organic matter (1.9-20.8\%) and $\mathrm{N}(0.08-0.55 \%)$. 
Edaphic variables allowed segregation in the ordination of the ED and WD groups. In general, ED species were associated with lower phosphorus levels and higher sand and nitrogen contents, while WD species showed an opposite tendency. The ED species that were mostly influenced by edaphic variables were $S$. tepuiensis, S. crenulata, S. striata, $S$. sp4 and $S$. sp5. The restricted geographic distribution in these species could be linked to their adaptations to the extreme limit of the range of soil textures and low availability of phosphorus that constitutes the niche of the family. The association between some ED species and high levels of nitrogen is interesting; however $\mathrm{N}$ and sand vectors have similar directions in the analysis, so the interpretation of this result must be made with caution. Gigasporaceae are predominantly found in environments with low levels of nitrogen and organic matter (Landis et al. 2004, Stürmer 2018), nevertheless, N: P stoichiometry can also influence AM fungal communities according to Johnson (2010). In the case of shrublands and meadows in LGS, prevalent condition of low availability of $\mathrm{P}$ plus high $\mathrm{N}$ seems to favor the presence of several species of the ED group of Gigasporaceae.

S. spinosissima, $S$. sp1 y $S$. sp2, show a lower influence of the edaphic variables (Figure 3). In the case of S. spinosissima, its greater adaptability to different edaphic conditions in LGS soils could be related with its more widespread distribution. So far it is the only species that has been found outside of LGS in others two localities of South America: Leticia (an adjacent region to the Guayana Shield in the Colombian Amazon) and the Atlantic Forest in North-eastern Brazil, a region with very poor and lixiviated soils that belongs to the Atlantic Shield (Peña-Venegas et al. 2006, Rabelo-Pereira et al. 2018). The finding of S. spinosissima in another geological shield of South America could have important implications from a biogeographical point of view. Considering that ecologically similar areas around LGS and Northeast of Brazil have been little explored regarding the presence of AMF, it is feasible that S. spinosissima and other species of ED Gigasporaceae group could indeed have a more widespread distribution in this region.

\section{Biogeography and phylogeny of Gigasporaceae with endemic distribution in La Gran Sabana}

In addition to the ecological issues mentioned above, historical or evolutionary factors such as speciation-extinction processes and the rise and fall of barriers against dispersion could have modelled AMF communities and have impacted the observed geographic distribution patterns. Indeed, the presence of endemic species in a particular locality could tentatively be attributed to two such historical scenarios: 1) these species originated in their present locality and did not get dispersed or 2) they persist today only in a small area of their previous geographical distribution, which was larger originally (Brown and Lomolino 1998).

The use of phylogenetic data to make inferences about the history of speciation and biotic assembly of AM communities in different geographic regions could be important for a better understanding of Glomeromycotan biogeography (Chaudhary et al. 2008). In this 
framework, the molecular characterization of the SSU-RNA $\mathrm{r}_{\mathrm{r}}$ gene and phylogenetic analyses of several Gigasporaceae species belonging to ED group ( $S$. spinosissima, $S$. crenulata, S. striata, $S$. sp1 and $S$. sp2) made by Lovera (2012) resulted particularly useful to understand the influence of past processes related to the evolutionary history of these species on their current geographic distributions. The molecular phylogeny inferred showed that S. spinosissima, S. crenulata, S. striata and S. sp. 1, constitute a monophyletic group within the genus Scutellospora (Figure 4). The monophyletic origin of these species suggests that the most plausible explanation for their regional endemism in LGS or in a bigger area in the Northeast of South America is the result of a process of in situ diversification combined with limitations for dispersal and/or establishment in other regions (scenario 1).

The in situ diversification scenario implies that speciation processes that occurred in sympatry, lead to the coexistence of phylogenetically close species. Congeneric coexistence is expected to be enhanced by divergence in functional traits (i.e. character displacement), yet among AMF, the existence of similar functional traits in nearby species (i.e. phylogenetic conservatism) has been well established at the family level (Maherali and Klironomos 2012, Hart and Reader 2002, Chagnon et al. 2013). In the case studied here, all the species that make up the clade $S$. spinosissima, $S$. crenulata, $S$. striata and $S$. sp1 coexist sympatrically in many of the ecosystems evaluated, particularly in the sclerophyllous shrubland (Table 1). The adaptation to particular niches, such as different soil types within a habitat edaphically heterogeneous, or the development of different functional compatibilities with host plants, would diminish inter-specific competition among this set of sympatric AMF. If this turns to be correct, niches in the species of this group would be segregated by their relatively high specialization to particular biotic or abiotic conditions (Drumbell et al. 2009). Such specialisation could also explain, at least partially, the endemism of these taxa and their inability to establish themselves in environments with ecological conditions different from those that prevail in this region.

Species in the family Gigasporaceae are generally considered to be inefficient dispersers due to their characteristically large spores produced in low numbers, root colonization only from spores and spore dormancy (Chagnon et al. 2013, Kivlin et al. 2014). However, the existence of cosmopolitan species within the family implies that in a large span of time, they can reach ranges of global distribution (Davison et al. 2015). The low genetic divergence found among S. spinosissima, S. crenulata, $S$. striata and $S$. sp. 1 (Figure 4), suggests that this clade diversified relatively recently, providing little time for dispersal events out of its hypothetical center of origin in LGS. The finding of $S$. spinosissima in the region of the Atlantic Shield in Brazil could be due to a recent event of dispersion and establishment in another environment with similar ecological conditions, or alternatively, could imply the existence of a larger previous distribution in the Northeast of South America that is now reduced only to the areas of the geological shields. The joint use of genetic markers more variable than the SSU gene and better analytical tools (e.g. coalescence-based models, approximate bayesian computation, etc.) will be necessary to 


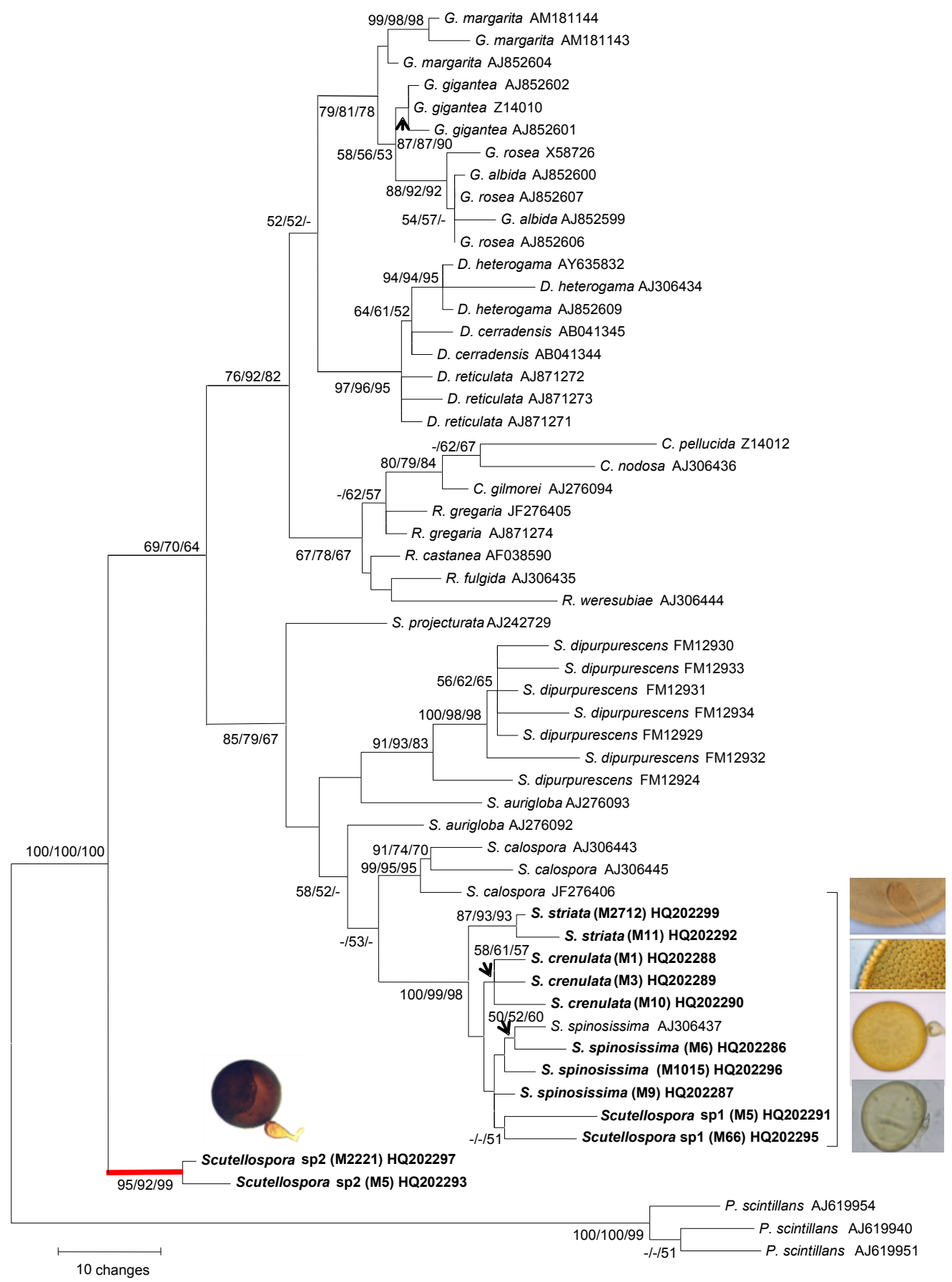

Figure 4. Phylogenetic inference of the Gigasporaceae family based on ribosomal SSU gene sequences, including Pacispora scintillans as external group. The tree shown is the consensus of 36 most parsimonious trees obtained with the Maximum Parsimony method with 100 replicates (length: 476, Consistency index, CI: 0.67437$)$. Node support values ( $>50 \%)$ obtained according to Neighbor-Joining, Maximum Likelihood and Maximum Parsimony methods (NJ/ML/MP) are indicated (only values $>50$ are shown). Sequences of species obtained in Lovera (2012) are highlighted in bold. Genera abreviatures: G: Gigaspora, D: Dentiscutata, C: Cetraspora, R: 
Racocetra y S: Scutellspora. Images of ED species are shown: a) S. striata, b) S. crenulata, c) $S$. spinosissima d) $S$. sp1 and e) $S$. sp2.

understand appropriately the patterns, tempo and mode of diversification in this clade of AMF. The recent diversification of this group of ED Gigasporaceae is according to Davison et al. (2015) who suggested that the diversification of the majority of current AM fungal virtual taxa occurred within the period of 4-30 million yr ago.

Finally, the phylogenetic analysis carried out in Lovera (2012) also showed that Scutellospora sp. 2 is phylogenetically distant from the rest of the species evaluated, forming part of a new basal lineage of Gigasporaceae (Figure 4). Morphologically, $S$. sp2 has a germination shield with the shape of an orb, which is a feature that has been observed as well in Bulbospora minima and S. pernambucana, two species recently discovered and described from Brazil, that also constitute ancestral lineages of the Gigasporaceae family (Silva et al. 2008, Marinho et al. 2014). S. sp2 and S. pernambucana coexist in forest habitats in LGS, unfortunately, the phylogenetic relationships among these species are yet unknown. Likewise, is important to obtain molecular data of S. tepuiensis and the rest of the putative new species found in this region, to improve understanding of the diversification processes of Gigasporaceae present in LGS.

\section{Conclusions}

The existence of abundant undescribed species, high rates of endemism probably associated with an in situ diversification processes, and the presence of a basal lineage to the family, make LGS a very interesting region for the study of the biogeography and evolution of Gigasporaceae. Furthermore, these results indicate that the region could represent a center of diversification for the genus Scutellospora or even for the whole family Gigasporaceae. Similarly, during the last decade, ten new species of Gigasporaceae have been described from Northeast Brazil, and about $60 \%$ of the species diversity of the family has been recorded in this region leading to propose that Brazil could constitute a center of diversification for this family (Marinho et al. 2014, de Souza et al. 2015). The ensemble of these results suggest that LGS in Venezuela, and probably the entire area of the Guayana Shield, in addition to the Atlantic Shield in the Northeast Brazil, must be considered as hotspots of diversification for Gigasporaceae. Based on this striking result we propose that the ecological conditions associated with these ancient geological shields (acidic, sandy and oligotrophic soils with presence of numerous endemism of plants) promote diversification processes in Gigasporaceae. Additionally, the biogeographic history of these tectonically stable areas, which have never been covered by the sea, could represent a refuge area for AMF species, as has been proposed by Stürmer et al. (2018). Our results pointed out to shrubland as the biome that hosts the greatest diversity and endemism of Gigasporaceae in LGS, a type of vegetation that is included in the category tropical grasslands, savannas, and shrublands which is considered an evolutionary hotspot 
for AMF by Partel et al. (2017). The high endemism of plants and the particular edaphic conditions present in LGS shrublands looks like the main drivers of the important diversification processes within Gigasporacea detected in these ecosystems.

The interesting patterns discovered in this study, together with the exciting questions that arise from them, highlight the importance of integrating phylogenetic information in studies about the ecology and biogeography of AMF. In this regard, it is necessary to increase sampling effort and enhance molecular data on the AMF species in this region in order to increase the understanding of the biogeographical patterns glimpsed so far.

\section{References}

Berry PE, Huber O, Holst BK (1995) Floristic analysis and phytogeography. In: Steyermark JA, Berry PE, Holst BK (eds) Flora of the Venezuelan Guayana, Vol 1: Introduction, pp. 161-191. Missouri Botanical Garden, St Louis \& Timber Press, Portland, OR

Briceño H O, Schubert C (1990) Geomorphology of the Gran Sabana, Guayana Shield, southeastern Venezuela. Geomorphology 3:125-141

*Chagnon PL et al. 2013. A trait-based framework to understand life history of mycorrhizal fungi. - Trends Plant Science. 18:484-491.

Chagnon P, Bradlley RL, Klironomos, JN (2015) Trait-based partner selection drives mycorrhizal network assembly. Oikos 124:1609-1616

Chaudhary VB, Cuenca G, Johnson NC (2017) Tropical-temperate comparison of landscape-scale arbuscular fungal species distributions. Diversity and Distributions 2017:1-13

Cuenca G, Lovera M (1992) Vesicular-arbuscular mycorrhizae in disturbed and revegetated sites from La Gran Sabana, Venezuela. Canadian Journal of Botany 70:73-79

Cuenca G, Lovera M (2010) Seasonal variation and distribution at different soil depths of arbuscular mycorrhizal fungi spores in a tropical sclerophyllous shrubland. Botany 88:54-64

Cuenca G, Herrera-Peraza RA (2008) Scutellospora striata sp nov, a newly described glomeromycotan fungus from La Gran Sabana, Venezuela. Mycotaxon 105: 79-87

Cuenca G, De Andrade Z, Escalante G (1998) Diversity of Glomalean spores from natural disturbed and revegetated communities growing on nutrient-poor tropical soils. Soil Biology and Biochemistry 30:711-719

Cuenca G, Lovera M, De Andrade Z, Meneses E (2003b) Why are so diverse the Scutellospora at La Gran Sabana Venezuela? Proceedings of the 4th International Conference on Mycorrhizae ICOM 4 Montreal, Quebec, Canada 593

Davison J, Moora M, Öpik M, Adholeya A, Ainsaar L, Bâ A, Burla S, Diedhiou AG, Hiiesalu I, Jairus T, Johnson NC, Kane A, Koorem K, Kochar M, Ndiaye C, Pärtel M, Reier Ü, Saks Ü, Singh R, Vasar M, Zobel M (2015) Global assessment of arbuscular mycorrhizal fungus diversity reveals very low endemism. Science 349:970-973

De Andrade Z, Furrazola E, Cuenca G (2017) Scutellospora tepuiensis sp. nov. from the highland tepuis of Venezuela. Mycotaxon 132:9-18

Drumbell AJ, Nelson M, Helgason T, Dytham C, Fitter AH. (2009) Relative roles of niche and neutral processes in structuring a soil microbial community. The ISME Journal 1-9

Finlay B J. (2002) Global dispersal of free-living microbial eukaryote species. Science 296: 1061

Fölster H, Dezzeo N (1994) La degradación de la vegetación. In: Ecología de la altiplanicie de la Gran Sabana (Guayana Venezolana) I. Investigaciones sobre la dinámica bosque-sabana en el sector S-E: Subcuencas de los ríos Yuruaní, Arabapó y Alto Kukenán. Dezzeo N (ed), Scientia Guaianae Nº4, pp 145-186. Caracas, Venezuela

Hart M, Reader RJ (2002) Taxonomic basis for variation in the colonization strategy of arbuscular mycorrhizal fungi. New Phytologist 153: 335-344

Herrera-Peraza RA, Cuenca G, Walker C (2001) Scutellospora crenulata a new species of Glomales from La Gran Sabana Venezuela. Canadian Journal of Botany 79: 674-678

Huber O. (1994) Arbustales. In: Ecología de la altiplanicie de la Gran Sabana (Guayana Venezolana) I. Investigaciones sobre la dinámica bosque-sabana en el sector S-E: Subcuencas de los ríos Yuruaní, Arabapó y Alto Kukenán. Dezzeo N (ed), Scientia Guaianae Nº4, pp 95-106. Caracas, Venezuela 
Huber O (1995) Vegetation. In: Steyermark JA, Berry PE, Holst BK (eds) Flora of the Venezuelan Guayana, Vol 1 : Introduction, pp. 97-160. Missouri Botanical Garden,St Louis \& Timber Press, Portland, OR

Huber O (2006) Herbaceous ecosystems on the Guayana Shield, a regional overview. Journal of Biogeography 33: 464-475.

Kiers ET, Duhamel M, Beesetty Y, Mensah JA, Franken O, Verbruggen E, Fellbaum CR, Kowalchuk GA, Hart M, Bago A, Palmer TM, West SA, Vandenkoornhuyse P, Jansa J, Bücking H. (2011) Reciprocal rewards stabilize cooperation in the mycorrhizal symbiosis. Science 333:888

Kivlin SN, Hawkes CV, Treseder K (2011) Global diversity and distribution of arbuscular mycorrhizal fungi. Soil Biology \& Biochemistry 43: 2294-2303

Kivlin S N, Winston G C, Goulden M L, Treseder K K (2014) Environmental filtering affects soil fungal community composition more than dispersal limitation at regional scales. Fungal Ecology http://dx.doi.org/10.1016/j.funeco.2014.04.004

Landis FC, Gargas A, Givnish TJ (2004) Relationships among arbuscular mycorrhizal fungi vascular plants and environmental conditions in oak savannas. New Phytol 164(3): 493-504

Lekberg Y, Koide RT, Rohr JR, Aldrich-Wolfe L, Morton JB (2007) Role of niche restrictions and dispersal in the composition of arbuscular mycorrhizal fungal communities. Journal of Ecology 95: 95-105

Lekberg Y, Meadow J, Rohr J R, Redecker D, Zabinski C A. (2011) Importance of dispersal and thermal environment for mycorrhizal communities: lessons from Yellowstone National Park. Ecology 92:1292-1302

Lovera M, Cuenca G (1996) Arbuscular mycorrhizal infection in Cyperaceae and Gramineae from natural, disturbed and restored savannas in La Gran Sabana, Venezuela. Mycorrhiza 6: 111-118

Lovera M , Cuenca G (2007) Diversidad de hongos micorrrízicos arbusculares (HMA) y potencial micorrízico del suelo de una sabana natural y una sabana perturbada de La Gran Sabana, Venezuela. Interciencia 32: 108-114

Lovera M (2007) Filogenia molecular de especies de hongos micorrízicos arbusculares del género "Scutellospora" presents en La Gran Sabana (Edo. Bolívar, Venezuela). MSc Thesis, Center for Advanced Studies, IVIC, Caracas, 91 pp.

Maherali H, Klironomos J N. (2007) Influence of phylogeny on fungal community assembly and ecosystem functioning Science 316: 1746

Marinho F, Silva GA, Ferreira A C A, Veras J S N, Sousa N M F, Goto B T, Maia L, Oehl F (2014) Bulbospora minima, a new genus and a new species in the Glomeromycetes from semi-arid Northeast Brazil. Sydowia 66:313-323

Oksanen J, Blanchet F G, Friendly M, Kindt R, Legendre P, McGlinn D, Minchin P R, O'Hara RB, Simpson G L, Solymos P, Stevens MHH, Szoecs E, Wagner H (2018) vegan:Community Ecology Package version 2.5-2.

Öpik, M. et al. 2009. Large-scale parallel 454 sequencing reveals host ecological group specificity of arbuscular mycorrhizalfungi in a boreonemoral forest. New Phytologist184: 424-437.

Öpik M, Vanatoa A, Vanatoa E, Moora M, Davison J, Kalwij JM, Reier Ü, Zobel M (2010) The online database MaarjAM reveals global and ecosystemic distribution patterns in arbuscular mycorrhizal fungi (Glomeromycota). New Phytologist 188: 223-241.

Peña-Venegas CP, Cardona Vanegas GI, Mazorra Valderrama A. (2006) Micorrizas arbusculares de la Amazonia colombiana. Catálogo ilustrado. Publicación del Instituto Amazónico de Investigaciones Científicas, SINCHI., Editorial Scripto Ltda., Colombia, $90 \mathrm{pp}$.

Rabelo Pereira CM, Silva D K A, Goto BT, Rosendahl S, Maia L (2018) Management practices may led to loss of arbuscular mycorrhizal fungal diversity in protected áreas of the Brazilian Atlantic Forest. Fungal Ecology 34: 50-58

Rosales J, Cuenca G, Ramírez N, De Andrade Z (1997) Native colonizing species and degraded land restoration in La Gran Sabana, Venezuela. Restoration Ecology 3: 147-155

*Rull V, Vegas-Villarrubia T, Montoya E (2016) The neotropical Gran Sabana region: palaeoecology and conservation. The Holocene

Schubert C, Huber O. (1989) La Gran Sabana, panorámica de una región. Lagoven booklets. Refolit Venezuela.

Schüßler A, Schwarzott D,Walker C (2001) A new fungal phylum the Glomeromycota: phylogeny and evolution. Mycological Research 105:1413-1421

Silva DKA, Freitas NO, Cuenca G, Maia LC, Oehl F (2008) Scutellospora pernambucana, a new fungal species in the Glomeromycetes with a characteristic germination orb. Mycotaxon 106: 361-370.

*Stürmer S L, Kemmelmeier K, Moreira B C, Kasuya M C M, Pereira GMD, Silva K. (2018a) Arbuscular mycorrhizal fungi (Glomeromycota) communities in tropical savannas of Roraima, Brazil. Mycological Progress

*Stürmer S L, Bever J D, Morton JB (2018b) Biogeography of arbuscular mycorrhizal fungi (Glomeromycota): a phylogenetic perspective on species distribution patterns. Mycorrhiza https://doi.org/10.1007/s00572-018-0864-6

Veresoglou SD, Caruso T, Rillig MC (2013) Modelling the environmental and soil factors that shape the niches of two common arbuscular mycorrhizal fungal families. Plant and Soil 368:507-518

Walker C, Cuenca G, Sánchez F (1998) Scutellospora spinosissima sp. nov. a newly described Glomalean fungus from low nutrient communities in Venezuela. Annals Botany 82: 721-725 